\title{
Protocol
}

\section{Analysis of RNA by Primer Extension}

\author{
Michael R. Green and Joseph Sambrook
}

For mapping the $5^{\prime}$ termini of mRNA molecules, primer extension is the method of choice. A purified oligonucleotide is end-labeled using polynucleotide kinase. The probe and a population of mRNA are allowed to hybridize, and the primers and template are used to carry out reverse transcription using an enzyme cloned from the Moloney murine leukemia virus. The primer extension products are separated on a denaturing polyacrylamide gel and analyzed by radiography.

It is essential that you consult the appropriate Material Safety Data Sheets and your institution's Environmental Health and Safety Office for proper handling of equipment and hazardous materials used in this protocol.

RECIPES: Please see the end of this protocol for recipes indicated by $<R>$. Additional recipes can be found online at http://cshprotocols.cshlp.org/site/recipes.

\section{Reagents}

Ammonium acetate $(10 \mathrm{M})$

$\left[\gamma-{ }^{32} \mathrm{P}\right]$ ATP $(10 \mathrm{mCi} / \mathrm{mL}, 7000 \mathrm{Ci} / \mathrm{mmol})$

Carrier RNA (yeast tRNA)

Chloroform

Denaturing polyacrylamide gel containing $8 \mathrm{M}$ urea

In many cases, a miniprotein gel apparatus (e.g., Bio-Rad Mini-PROTEAN $13 \mathrm{~cm} \times 13 \mathrm{~cm} \times 0.75 \mathrm{~mm}$ ) can be used to analyze radiolabeled primer extension products (see Tables 1 and 2 in Protocol: Mapping RNA with Nuclease S1 [Green and Sambrook 2021a] and the note to the entry for Polyacrylamide gel electrophoresis in the Materials list of Protocol: Mapping RNA with Nuclease S1 [Green and Sambrook 2021a]). The method used to prepare a minidenaturing polyacrylamide gel is described in Step 1 of Protocol: Mapping RNA with Nuclease S1 (Green and Sambrook 2021a). The preparation of larger gels is described in Protocol: Separation of RNA according to Size: Electrophoresis of RNA through Denaturing Urea Polyacrylamide Gels (Green and Sambrook 2021b)

Dithiothreitol (1 M)

DNA markers, radiolabeled, for gel electrophoresis

See Introduction: Mapping RNA (Green and Sambrook 2021c) (the section Optimizing Primer Extension Reactions).

Ethanol

Formamide loading buffer for RNA gels $<\mathrm{R}>$

Input RNA to be analyzed

Preparations of poly $(A)^{+} R N A$ are preferred, especially when setting up primer extension reactions for the first time or when preparations of total RNA produce extension products of different lengths.

From the Molecular Cloning collection, edited by Michael R. Green and Joseph Sambrook.

(C) 2021 Cold Spring Harbor Laboratory Press

Cite this protocol as Cold Spring Harb Protoc; doi:10.1101/pdb.prot101840 
M.R. Green and J. Sambrook

$\mathrm{KCl}(1.25 \mathrm{M})$

Oligonucleotide primer

These primers should be 20-30 nt in length and preferentially purified through Sep-Pak chromatography and by gel electrophoresis. Crude preparations of oligonucleotides give rise to higher backgrounds on the autoradiogram, especially in the area of the film corresponding to the low-molecular-weight region of the polyacrylamide gel. Resuspend the purified oligonucleotide at a concentration of $\sim 60 \mathrm{ng} / \mu \mathrm{L}(5-7 \mathrm{pmol} / \mu \mathrm{L})$ in TE (pH 7.6).

Phenol

Polynucleotide kinase

Primer extension mix for RNA analysis $<\mathrm{R}>$

Protein inhibitor of RNase

These inhibitors are sold by several manufacturers under various trade names (e.g., RNasin from Promega, PRIME Inhibitor, 5 Prime $\rightarrow 3$ Prime). For more details, see the section Inhibitors of RNases in Introduction: How to Win the Battle with RNase (Green and Sambrook 2019).

\section{Reverse transcriptase}

A cloned version of reverse transcriptase encoded by the Moloney murine leukemia virus (Mo-MLV) is the enzyme of choice in this protocol. Mutants of the enzyme that lack RNase H activity (e.g., StrataScript, Stratagene) have some advantages over the wild-type enzyme because they produce higher yields of full-length extension product and work equally well at both $47^{\circ} \mathrm{C}$ and $37^{\circ} \mathrm{C}$ (for review, see Gerard et al. 1997).

Reverse transcriptase supplied by different manufacturers varies in its activity per unit. When using a new batch of enzyme, set up a series of extension reactions containing equal amounts of poly $(A)^{+} R N A$ and oligonucleotide primer, and different amounts of enzyme. If possible, the primer should be specific for an mRNA present at moderate abundance in the preparation of poly $(A)^{+} R N A$. Assay the products of each reaction by gel electrophoresis as described in this protocol. Use the minimal amount of enzyme required to produce the maximum yield of extension product. The units used in this protocol work well with most batches of StrataScript.

Sodium acetate (3 $\mathrm{M}, \mathrm{pH} 5.2)$

TE buffer, $10 \times<\mathrm{R}>$

Prepare TE ( $p H 7.6)$.

Trichloroacetic acid (1\% and 10\% TCA)

Dilute $100 \%$ stock solution $1 / 10$ and $1 / 100$ just before use. Chill the working solutions in ice.

Water baths preset to $42^{\circ} \mathrm{C}$ and $95^{\circ} \mathrm{C}$, and the appropriate annealing temperature (see Step 12) Whatman $3 \mathrm{MM}$ filter paper (or equivalent)

Prepare all reagents used in this protocol with DEPC-treated $\mathrm{H}_{2} \mathrm{O}$ (see Introduction: How to Win the Battle with RNase [Green and Sambrook 2019]).

\section{Preparation of the Oligonucleotide Probe}

1. Phosphorylate the oligonucleotide primer in a reaction containing:

$\begin{array}{lr}\text { Oligonucleotide primer }(5-7 \text { pmol or } 60 \mathrm{ng}) & 1 \mu \mathrm{L} \\ \text { Distilled deionized } \mathrm{H}_{2} \mathrm{O} & 6.5 \mu \mathrm{L} \\ \text { Kinase buffer }(10 \times) & 1.5 \mu \mathrm{L} \\ \text { Polynucleotide kinase }(\sim 10 \text { units }) & 1 \mu \mathrm{L} \\ {[\gamma \text {-32P]ATP }(7000 \mathrm{Ci} / \mathrm{mmol})} & 2 \mu \mathrm{L}\end{array}$

Incubate the reaction for $60 \mathrm{~min}$ at $37^{\circ} \mathrm{C}$.

The final concentration of radiolabeled ATP in the reaction should be $\sim 30 \mathrm{~nm}$.

2. Stop the kinase reaction with the addition of $500 \mu \mathrm{L}$ of TE (pH 7.6). Add $25 \mu \mathrm{g}$ of carrier RNA. 
3. Add $400 \mu \mathrm{L}$ of equilibrated phenol ( $\mathrm{pH} 8.0$ ) and $400 \mu \mathrm{L}$ of chloroform (or $800 \mu \mathrm{L}$ of commercial phenol:chloroform [1:1]). Vortex vigorously for $20 \mathrm{sec}$. Separate the aqueous and organic phases by centrifugation for $2 \mathrm{~min}$ in a microcentrifuge.

4. Transfer the aqueous layer to a fresh sterile microcentrifuge tube and extract with $800 \mu \mathrm{L}$ of chloroform. Vortex vigorously for $20 \mathrm{sec}$. Separate the aqueous and organic phases by centrifugation for $2 \mathrm{~min}$ in a microcentrifuge. Again transfer the aqueous layer to a fresh sterile microcentrifuge tube.

5. Repeat Step 4.

6. Add $55 \mu \mathrm{L}$ of sterile $3 \mathrm{~m}$ sodium acetate ( $\mathrm{pH} 5.2$ ) and $1 \mathrm{~mL}$ of ethanol to the aqueous layer from Step 5. Mix by vortexing, and store the solution for at least $1 \mathrm{~h}$ at $-70^{\circ} \mathrm{C}$.

7. Collect the precipitated oligonucleotide primer by centrifugation at maximum speed for $15 \mathrm{~min}$ at $4^{\circ} \mathrm{C}$ in a microcentrifuge. Remove and discard the radioactive supernatant. Wash the pellet in $70 \%$ ethanol and centrifuge again. Discard the supernatant and dry the precipitate in the air. Dissolve the precipitate in $500 \mu \mathrm{L}$ of TE (pH 7.6).

8. Count $2 \mu \mathrm{L}$ of radiolabeled oligonucleotide primer in $10 \mathrm{~mL}$ of scintillation fluid in a liquid scintillation counter. Calculate the specific activity of the radiolabeled primer assuming $80 \%$ recovery. The specific activity should be $\sim 2 \times 10^{6} \mathrm{cpm} / \mathrm{pmol}$ of primer.

\section{Hybridization and Extension of the Oligonucleotide Primer}

9. Mix $10^{4}$ to $10^{5} \mathrm{cpm}(20-40 \mathrm{fmol})$ of the DNA primer with $0.5-150 \mu \mathrm{g}$ of the RNA to be analyzed. Add 0.1 volume of $3 \mathrm{~m}$ sodium acetate ( $\mathrm{pH} 5.2$ ) and 2.5 volumes of ethanol. Store the solution for $60 \mathrm{~min}$ at $-70^{\circ} \mathrm{C}$, and then recover the RNA by centrifugation at maximum speed for $10 \mathrm{~min}$ at $4^{\circ} \mathrm{C}$ in a microcentrifuge. Wash the pellet with $70 \%$ ethanol and centrifuge again. Carefully remove all of the ethanol, and store the pellet at room temperature until the last visible traces of ethanol have evaporated.

The primer should be in 10 -fold molar excess over the template RNA (see the discussion on Optimizing Primer Extension Reactions in Introduction: Mapping RNA [Green and Sambrook 2021c]).

10. Resuspend the pellets in $8 \mu \mathrm{L}$ of TE ( $\mathrm{pH}$ 7.6) per tube. Pipette the samples up and down several times to dissolve the pellets.

11. Add $2.2 \mu \mathrm{L}$ of $1.25 \mathrm{M} \mathrm{KCl}$. Vortex the samples gently, and then deposit the fluid in the base of the tubes by centrifuging for $2 \mathrm{sec}$ in a microcentrifuge.

12. Place the oligonucleotide/RNA mixtures in a water bath set at the appropriate annealing temperature. Incubate the samples for $15 \mathrm{~min}$ at the optimum temperature, as determined in preliminary experiments (see the discussion on Optimizing Primer Extension Reactions in Introduction: Mapping RNA [Green and Sambrook 2021c]).

The kinetics of annealing between the oligonucleotide primer and the mRNA template are remarkably rapid under typical primer extension conditions, in which the primer is in excess of the target mRNA. For this reason, the time of annealing in Step 12 can be limited to $15 \mathrm{~min}$. Some protocols include elaborate heating and cooling routines at this step, but in our hands, these Byzantine variations are rarely necessary.

13. While the oligonucleotide and RNA are annealing, supplement an aliquot of primer extension mix with dithiothreitol and reverse transcriptase as follows: Thaw a $300-\mu \mathrm{L}$ aliquot of primer extension mix on ice and then add $3 \mu \mathrm{L}$ of $1 \mathrm{~m}$ dithiothreitol and reverse transcriptase to a concentration of $1-2$ units $/ \mu \mathrm{L}$. Add 0.1 unit $/ \mu \mathrm{L}$ of protein inhibitor of RNase, gently mix by inverting the tube several times, and store it on ice.

It is possible to establish the DNA sequence of a primer-extended product by including dideoxynucleotides (terminators) in the reaction mix. In a $5^{\prime}$-end mapping experiment, knowing the exact sequence of the primer-extended product allows precise positioning of the end in the $5^{\prime}$-flanking region of the gene. This approach has been successful in many laboratories when examining $m R N A s$ that are relatively abundant in the cell (class I antigens, rat liver steroid $5 \alpha$-reductase $m R N A$, and yeast alcohol dehydrogenase 2 mRNA). For protocols on primer extension sequencing, see Geliebter et al. (1986) and Hahn et al. (1989). 
M.R. Green and J. Sambrook

14. Remove the tubes containing the oligonucleotide primer and RNA from the water bath, and deposit the fluid in the bases of the tubes by centrifuging for $2 \mathrm{sec}$ in a microcentrifuge.

15. Add $24 \mu \mathrm{L}$ of supplemented primer extension mix to each tube. Gently mix the solution in the tubes, and again deposit the liquid at the tube bottoms by centrifugation.

16. Incubate the tubes for $1 \mathrm{~h}$ at $42^{\circ} \mathrm{C}$ to allow the primer extension reaction to proceed.

17. Terminate the primer extension reactions by the addition of $200 \mu \mathrm{L}$ of TE (pH 7.6), $100 \mu \mathrm{L}$ of equilibrated phenol ( $\mathrm{pH} 8.0$ ), and $100 \mu \mathrm{L}$ of chloroform. Vortex for $20 \mathrm{sec}$. Separate aqueous and organic phases by centrifugation for $4 \mathrm{~min}$ at room temperature in a microcentrifuge.

There is often a considerable amount of radioactivity remaining in the well of the polyacrylamide gel after electrophoresis (see Step 22 below). In our hands, there is rarely a correlation between the amount of this radioactivity in the well and the amount of the desired primer extension product. The aggregated material in the well may represent longer extension products derived by spurious priming of the oligonucleotide on nontarget mRNAs or contaminating genomic DNA templates. Rarely, this background can represent aggregates of the desired primer extension product with molecules of RNA.

If there is a significant amount of radioactivity trapped in the well of the gel, try treating the primer-extended products after Step 16 with RNase: Add $1 \mu \mathrm{L}$ of $0.5 \mathrm{M} \mathrm{EDTA}(\mathrm{pH}$ 8.0) and $1 \mu \mathrm{L}$ of DNase-free pancreatic $R$ Nase $\left(5 \mathrm{mg} / \mathrm{mL}\right.$ ) to each tube, and incubate the reactions for $30 \mathrm{~min}$ at $37^{\circ} \mathrm{C}$. Add $150 \mu \mathrm{L}$ of TE (pH 7.6) containing $0.1 \mathrm{M} \mathrm{NaCl}$ and $200 \mu \mathrm{L}$ of phenol:chloroform. Vortex for $30 \mathrm{sec}$, and centrifuge at maximum speed for 5 min at room temperature in a microcentrifuge. Continue the protocol at Step 18. Alternatively, the primer-extended products from Step 16 can be treated with $\mathrm{NaOH}$ to hydrolyze the RNA template before electrophoresis: Add $1.0 \mu \mathrm{L}$ of $10 \mathrm{~N} \mathrm{NaOH}$ to the solution, and incubate for $10 \mathrm{~min}$ at room temperature. Neutralize the $\mathrm{NaOH}$ by the addition of $1 / 10$ volume of $3 \mathrm{~m}$ sodium acetate $(\mathrm{pH} 5.2)$, and continue the protocol at Step 17.

18. Precipitate the nucleic acids by the addition of $50 \mu \mathrm{L}$ of $10 \mathrm{M}$ ammonium acetate and $700 \mu \mathrm{L}$ of ethanol. Mix well by vortexing, and incubate the ethanol precipitations for at least $1 \mathrm{~h}$ at $-70^{\circ} \mathrm{C}$.

Purification and Analysis of the Primer Extension Products

19. Collect the precipitated nucleic acids by centrifugation for $10 \mathrm{~min}$ at $4^{\circ} \mathrm{C}$ in a microcentrifuge. Carefully rinse the pellets with $400 \mu \mathrm{L}$ of $70 \%$ ethanol. Centrifuge again for $5 \mathrm{~min}$ at $4^{\circ} \mathrm{C}$, and remove the $70 \%$ ethanol rinse with a pipette. Store the open tubes at room temperature until all visible traces of ethanol have evaporated.

20. Dissolve the nucleic acid precipitates in $10 \mu \mathrm{L}$ of formamide loading buffer. Pipette the samples up and down to assist resuspension.

21. Heat the samples for $8 \mathrm{~min}$ at $95^{\circ} \mathrm{C}$. Then plunge the tubes into an ice-water bath, and immediately analyze the primer extension products by electrophoresis through a denaturing polyacrylamide gel.

End-labeled DNA fragments of known size should be used as molecular-weight markers on the gel (see the discussion on Optimizing Primer Extension Reactions in Introduction: Mapping RNA [Green and Sambrook 2021c]).

22. After the tracking dyes have migrated an appropriate distance through the gel (Table 2 of Protocol: Mapping RNA with Nuclease S1 [Green and Sambrook 2021a]), turn off the power supply and dismantle the electrophoresis setup. Gently pry up one edge of the larger glass plate and slowly remove the plate from the gel. Cut off one corner of the gel for orientation purposes.

Wear eye protection when prying the glass plates apart.

23. If a polyacrylamide gel $1.0 \mathrm{~mm}$ in thickness was used, fix the gel in TCA. Transfer the glass plate containing the gel to a tray containing an excess of $10 \%$ TCA. Gently rock or rotate the tray for 10 $\mathrm{min}$ at room temperature.

The gel will usually float off the glass plate during this incubation. Do not allow the gel to fold up on itself.

This step is not necessary if a thin gel (0.4 mm thick) was used. In this case, proceed to Step 26. 
24. Pour off the $10 \%$ TCA solution, and replace it with an excess of $1 \%$ TCA. Gently rock or rotate the tray for $5 \mathrm{~min}$ at room temperature.

25. Pour off the $1 \%$ TCA solution, and briefly rinse the fixed gel with distilled deionized $\mathrm{H}_{2} \mathrm{O}$. Lift the glass plate together with the gel out of the tray and place them on a flat benchtop. Apply paper towels or KimWipes to the sides of the gel to remove excess $\mathrm{H}_{2} \mathrm{O}$.

Do not place towels on top of gel.

26. Cut a piece of Whatman $3 \mathrm{MM}$ filter paper (or equivalent) that is $1 \mathrm{~cm}$ larger than the gel on all sides. Transfer the gel to the filter paper by laying the paper on top of the gel and inverting the glass plate.

27. Remove the plate, and dry the gel on a heat-assisted vacuum-driven gel dryer for $1.0-1.5 \mathrm{~h}$ at $60^{\circ} \mathrm{C}$.

28. Establish an image of the gel using autoradiography or phosphorimaging.

\section{RELATED INFORMATION}

For additional details on primer extension assays, see Introduction: Mapping RNA (Green and Sambrook 2021c) (specifically the sections Primer Extension and Optimizing Primer Extension Reactions).

Formamide Loading Buffer for RNA Gels

Deionized formamide

$80 \%(\mathrm{w} / \mathrm{v})$

$10 \mathrm{~mm}$

EDTA (pH 8.0)

Xylene cyanol FF

$1 \mathrm{mg} / \mathrm{mL}$

Bromophenol blue

$1 \mathrm{mg} / \mathrm{mL}$

Purchase a distilled deionized preparation of formamide and store in small aliquots under nitrogen at $-20^{\circ} \mathrm{C}$.

Alternatively, deionize reagent-grade formamide by stirring on a magnetic stirrer with Dowex XG8 mixed bed resin for $1 \mathrm{~h}$ and filtering it twice through Whatman No. 1 paper. Store deionized formamide in small aliquots under nitrogen at $-70^{\circ} \mathrm{C}$.

Primer Extension Mix for RNA Analysis

\begin{tabular}{lcc} 
Reagent & $\begin{array}{c}\text { Quantity } \\
\text { (for } 10 \mu \mathrm{mL})\end{array}$ & $\begin{array}{c}\text { Final } \\
\text { concentration }\end{array}$ \\
\hline Tris-Cl $(1 \mathrm{M}, \mathrm{pH} 8.4$, at room temperature) & $200 \mu \mathrm{L}$ & $20 \mathrm{~mm}$ \\
$\mathrm{MgCl}_{2}(1 \mathrm{M})$ & $100 \mu \mathrm{L}$ & $10 \mathrm{mM}$ \\
dNTP solution containing all four dNTPs $(100 \mathrm{mM})$ & $160 \mu \mathrm{L}$ & $1.6 \mathrm{mM}$ \\
Actinomycin D $(5 \mathrm{mg} / \mathrm{mL})$ & $100 \mu \mathrm{L}$ & $50 \mu \mathrm{g} / \mathrm{mL}$ \\
Dissolve actinomycin D in methanol at a concentration of $5 \mathrm{mg} / \mathrm{mL}$ before supplementing the primer \\
extension mix. Store the actinomycin D stock solution at $-20^{\circ} \mathrm{C}$ in the dark.
\end{tabular}


M.R. Green and J. Sambrook

TE Buffer, $10 \times$

$100 \mathrm{~mm}$ Tris- $\mathrm{Cl}$ (desired $\mathrm{pH})$

$10 \mathrm{~mm}$ EDTA (pH 8.0)

Sterilize solutions by autoclaving for $20 \mathrm{~min}$ at $15 \mathrm{psi}\left(1.05 \mathrm{~kg} / \mathrm{cm}^{2}\right)$ on liquid cycle. Store the buffer at room temperature.

\section{ACKNOWLEDGMENTS}

This protocol was developed by Thomas Südhof and supplied by Daphne Davis.

\section{REFERENCES}

Geliebter J, Zeff RA, Melvold RW, Nathenson SG. 1986. Mitotic recombination in germ cells generated two major histocompatibility complex mutant genes shown to be identical by RNA sequence analysis: $K^{b m 9}$ and $K^{b m 6}$. Proc Natl Acad Sci 83: 3371-3375.

Gerard GF, Fox DK, Nathan M, D’Alessio JM. 1997. Reverse transcriptase. The use of cloned Moloney murine leukemia virus reverse transcriptase to synthesize DNA from RNA. Mol Biotechnol 8: 61-77.

Green MR, Sambrook J. 2019. How to win the battle with RNase. Cold Spring Harb Protoc doi: 10.1101/pdb.top 101857.
Green MR, Sambrook J. 2021a. Mapping RNA with nuclease S1. Cold Spring Harb Protoc doi: 10.1101/pdb.prot101824.

Green MR, Sambrook J. 2021b. Separation of RNA according to size: Electrophoresis of RNA through denaturing urea polyacrylamide gels. Cold Spring Harb Protoc doi: 10.1101/pdb.prot101766.

Green MR, Sambrook J. 2021c. Mapping RNA. Cold Spring Harb Protoc doi: $10.1101 /$ pdb.top 101816

Hahn CS, Strauss EG, Strauss JM. 1989. Dideoxy sequencing of RNA using reverse transcriptase. Methods Enzymol 180: 121-130. 


\section{Analysis of RNA by Primer Extension}

Michael R. Green and Joseph Sambrook

Cold Spring Harb Protoc; doi: 10.1101/pdb.prot101840

\begin{tabular}{cc}
$\begin{array}{c}\text { Email Alerting } \\
\text { Service }\end{array}$ & Receive free email alerts when new articles cite this article - click here. \\
\hline $\begin{array}{c}\text { Subject } \\
\text { Categories }\end{array}$ & Browse articles on similar topics from Cold Spring Harbor Protocols. \\
& Electrophoresis (57 articles) \\
& Electrophoresis of Nucleic Acids (62 articles) \\
& Electrophoresis of Nucleic Acids, general (49 articles) \\
& Molecular Biology, general (1293 articles) \\
& mRNA (132 articles) \\
& Probes (92 articles) \\
& Probes, general (72 articles) \\
& Radiolabeled Probes (54 articles) \\
& RNA (317 articles) \\
& RNA, general (269 articles) \\
\hline
\end{tabular}

